\title{
Effect of Three Commonly Consumed Beverages on Surface Roughness of Polished and Glazed Zirconia-Reinforced Lithium Silicate Glass Ceramics
}

\section{Farnaz Firouz ${ }^{1}$, Fariborz Vafaee ${ }^{2}$, Zahra Khamverdi ${ }^{3}$, Sara Khazaei ${ }^{1}$, Somayeh Ghorbani Gholiabad¹, Mahsa Mohajeri ${ }^{*}$}

1. Department of Prosthodontics, Dental Faculty, Hamadan University of Medical Sciences, Hamadan, Iran

2. Dental Implant Research Center, Department of Prosthodontics, Dental Faculty, Hamadan University of Medical Sciences, Hamadan, Iran

3. Department of Restorative Dentistry, Dental Faculty, Hamadan University of Medical Sciences, Hamadan, Iran

Article Info A B S T R A C T

\section{Article type:}

Original Article

\section{Article History:}

Received: 13 January 2018

Accepted: 21 May 2018

Published: 30 August 2019

\section{* Corresponding author:}

Department of Prosthodontics, Dental Faculty, Hamadan University of Medical

Sciences, Hamadan, Iran

Email: mohajeri_mahsa@yahoo.com
Objectives: This study aimed to assess the effect of three commonly consumed beverages on surface roughness of polished and glazed zirconia-reinforced lithium silicate (ZLS) glass ceramics.

Materials and Methods: In this experimental study, 104 rectangular specimens were cut from Vita Suprinity blocks with 2 mm thickness. After ultrasonic cleaning and firing of the specimens, they were finished and polished in two groups. Specimens in the first group were polished using a 2-step polishing kit while the second group specimens were glazed and heated in a porcelain firing oven according to the manufacturer's instructions. Baseline surface roughness was measured using a profilometer. Specimens in each group were then randomly divided into 4 subgroups $(n=13)$ for immersion in artificial saliva (control group), cola, orange juice and black tea. Surface roughness was measured again and data were analyzed using two-way ANOVA.

Results: The highest and the lowest mean Ra were found in orange juice and saliva subgroups, respectively in both glazed and polished groups. The Ra values of both polished and glazed groups significantly increased after immersion in orange juice and cola $(\mathrm{P}<0.05)$. The polished surfaces showed insignificantly higher surface roughness compared with glazed surfaces $(\mathrm{P}>0.05)$.

Conclusion: Orange juice and cola significantly increased the surface roughness of both polished and glazed ZLS ceramics. Type of surface finishing (polishing versus glazing) had no significant effect on the surface roughness of specimens following immersion in different beverages.

Keywords: Surface Properties; Dental Porcelain; Dental Polishing; Lithium Compounds; Silicates

$>$ Cite this article as: Firouz F, Vafaee F, Khamverdi Z, Khazaei S, Ghorbani Gholiabad S, Mohajeri M. Effect of Three Commonly Consumed Beverages on Surface Roughness of Polished and Glazed Zirconia-Reinforced Lithium Silicate Glass Ceramics. Front Dent. 2019;16(4):296-302. doi:

This work is published as an open access article distributed under the terms of the Creative Commons Attribution 4.0 License (http://creativecommons.org/licenses/by-nc/4). Non-commercial uses of the work are permitted, provided the original work is properly cited. 


\section{INTRODUCTION}

Dental ceramics are increasingly used in esthetic and restorative dentistry $[1,2]$. They account for a high percentage of dental restorations because they highly resemble the texture and color of natural teeth. Biocompatibility and polishability (in order to minimize plaque accumulation and subsequently prevent gingival inflammation) are some other favorable characteristics of dental ceramics [3]. Furthermore, the brisk development of computer-aided design/computer-aided manufacturing (CAD/CAM) technology further increased the application of ceramics in dentistry [4]. At present, monolithic ceramic restorations have gained increasing popularity due to their enhanced fabrication process and lower frequency of complications such as chipping and delamination of the veneering ceramics $[5,6]$. Among the materials used for the fabrication of CAD/CAM monolithic restorations, zirconia-reinforced lithium silicate (ZLS) glass ceramics have both favorable mechanical properties of zirconia and esthetic properties of glass ceramics; therefore, they are used for the fabrication of a wide range of restorations such as inlays, onlays, partial crowns, veneers and anterior and posterior crowns $[7,8]$. Recently, VITA introduced a new ZLS glass ceramic (Vita Suprinity PC; Vita Zahnfabrik) enriched with approximately $10 \mathrm{wt} \%$ zirconia [5].

Following the fabrication of different types of restorations, they often require chairside adjustment of occlusion and cervical contour with a fine-grain diamond rotary cutting instrument [9-13]. Although these adjustments are necessary for correction of contour and/or improvement of esthetics, this process can damage the glaze layer and create a rough and coarse surface, which can enhance dental plaque accumulation and consequent development of caries and periodontal disease [11,14-19]. A rough surface also adversely affects the color and light reflection of restoration, and the higher the roughness, the lower the optical reflection would be [20-22]. Roughness resulted from restoration adjustment may increase the surface flaws and consequently decrease the porcelain strength [23].
Higher roughness is not only a side effect of chairside adjustment, but also a consequence of porcelain degradation as the result of exposure to acidic agents [24-30]. This phenomenon can result in release of potentially cytotoxic components from the ceramic $[27,31]$.

The effect of acidic agents on the surface of different types of dental porcelain has been documented in some studies but there is not enough evidence about the alterations caused by acidic agents on the surface of ZLS ceramics. The aim of this study was to evaluate the effect of commonly consumed beverages (cola, orange juice and black tea) on surface roughness of polished and glazed ZLS glass ceramics. The null hypothesis was that different beverages would not increase the surface roughness of polished and glazed ceramic specimens.

\section{MATERIALS AND METHODS}

In this in vitro experimental study, the CAD/CAM ZLS glass ceramic blocks (Vita Suprinity PC; Vita Zahnfabrik, Bad Säckingen, Germany) were used to fabricate the specimens. A total of 104 rectangular specimens were sectioned from Vita Suprinity blocks $(18 \times 14 \times 12 \mathrm{~mm})$ with an average thickness of $2 \mathrm{~mm}$ using water-cooled lowspeed diamond saw (Vari/cut VC-50; Series 15 LC diamond, Leco Corp., MI, USA). The specimens were then cleaned ultrasonically and were completely crystalized using a porcelain firing oven (Programat EP5000; Ivoclar Vivadent AG, NY, USA) according to the manufacturer's instructions. After the crystallization cycle, a single operator polished the specimens with a low-speed hand piece and 600-grit silicon carbide papers and the specimens were then randomly allocated into two groups. Specimens in the first group were polished using a 2-step polishing kit (Vita Suprinity Polishing Set technical; VITA Zahnfabrik, Bad Säckingen, Germany) and a low-speed hand-piece. In the second group, a thin layer of glaze material (Vita Akzent Plus Glaze LT; Vita Zahnfabrik, Bad Säckingen, Germany) was applied on the specimens and they were heated in a porcelain firing oven, 
according to the manufacturer's instructions. The specimens were immersed in distilled water at $37^{\circ} \mathrm{C}$ for 24 hours before and after measurement of baseline surface roughness (Ra) using a profilometer (TR200 Plus portable surface roughness tester; Testech NDT, Beijing, China). The test specimens in each group were randomly divided into 4 subgroups $(n=13)$ for immersion in the following beverages:

Subgroup A: Immersed in artificial saliva (control group)

Subgroup B: Immersed in orange juice

Subgroup C: Immersed in cola

Subgroup D: Immersed in black tea

Table 1 presents the information of the beverages used in this study.

Specimens in subgroup A were immersed in artificial saliva and incubated at $37^{\circ} \mathrm{C}$ for 125 hours. Specimens in subgroups B, C and D were subjected to 5000 thermal cycles in a thermocycler (MSCT-3; Convel, Aracatuba, Brazil) in orange juice $\left(5^{\circ} \mathrm{C}\right)$, cola $\left(5^{\circ} \mathrm{C}\right)$ and black tea $\left(5^{\circ} \mathrm{C}\right)$ for aging with 30 seconds of transfer time and 30 seconds of dwell time. After each cycle of immersion in the aforementioned beverages, the specimens were immersed in artificial saliva $\left(37^{\circ} \mathrm{C}\right)$ for 30 seconds to better simulate the oral clinical condition. After thermocycling, the specimens were cleaned under running water using a brush and dried before surface roughness measurement [32-34].
The surface roughness ( $\mathrm{Ra}$ ) of the specimens was then measured again as described for measurement of baseline surface roughness. The mean and standard deviation of surface roughness were then reported. The data were statistically analyzed using SPSS version 16 (SPSS Inc., IL, Chicago, USA). The effect of beverages and polishing procedure on surface roughness was evaluated using two-way ANOVA and Tukey's HSD test.

\section{RESULTS}

Table 2 shows the mean Ra value and standard deviation of the groups $(n=13)$. The results of two-way ANOVA indicated that the interaction effect of type of beverage and polishing method on surface roughness was not significant $(\mathrm{P}>0.05)$. In other words, different beverages had the same effect on polished and glazed specimens $(\mathrm{P}>0.05)$.

According to the results, there was no significant difference in the mean Ra value of glazed and polished groups. The mean $\mathrm{Ra}$ value was 0.046 for the glazed group and 0.056 for the polished group. The type of beverage had a significant effect on the mean surface roughness.

The Ra values of both polished and glazed groups significantly increased after immersion in orange juice and cola $(\mathrm{P}<0.05)$. The surface roughness also increased in the saliva and tea subgroups but not significantly (P>0.05, Table 3).

Table 1. Characteristics of the materials used in this study

\begin{tabular}{|c|c|c|c|c|}
\hline $\begin{array}{l}\text { Immersion } \\
\text { Solution }\end{array}$ & Manufacturer & Chemical Composition & pH & $\begin{array}{l}\text { Immersion } \\
\text { Temperature }\end{array}$ \\
\hline Artificial saliva & $\begin{array}{l}\text { Professional } \\
\text { Dietetics, Italy }\end{array}$ & $\begin{array}{l}\mathrm{KCl}(0.4 \mathrm{~g} \mathrm{~L}-1), \mathrm{NaCl}(0.4 \mathrm{~g} \mathrm{~L}-1) \\
\mathrm{CaCl} 2 \_2 \mathrm{H} 2 \mathrm{O}(0.906 \mathrm{~g} \mathrm{~L}-1), \\
\mathrm{NaH} 2 \mathrm{PO} 4 \_2 \mathrm{H} 2 \mathrm{O}(0.690 \mathrm{~g} \mathrm{~L}-1) \\
\mathrm{Na} 2 \mathrm{~S} \text {-9H2O }(0.005 \mathrm{~g} \mathrm{~L}-1), \text { and urea } \\
(1 \mathrm{~g} \mathrm{~L}-1)\end{array}$ & 6.5 & $37^{\circ} \mathrm{C}$ \\
\hline Orange juice & Sunich, Iran & $\begin{array}{l}\text { Orange juice, water, sugar, orange } \\
\text { pulp, natural flavors, antioxidant } \\
\text { ascorbic acid, and citric acid }\end{array}$ & 3.5 & $5 \div \mathrm{C}$ \\
\hline Cola & Coca-Cola & $\begin{array}{l}\text { Carbonated water, sugar, cola nut } \\
\text { extract, yellow dye IV, acidulate INS } \\
338 \text {, and natural flavors }\end{array}$ & 2.4 & $5^{\circ} \mathrm{C}$ \\
\hline Tea & Tetley & Tea leaves & 4.9 & $55^{\circ} \mathrm{C}$ \\
\hline
\end{tabular}


Table 2. Mean and standard deviation (SD) of Ra values of glazed and polished ceramic groups

\begin{tabular}{|lllll} 
Method & Solution & Mean & SD & N \\
& Saliva & .002 & .006 & 13 \\
& Orange juice & .092 & .085 & 13 \\
Glazed & Coca-Cola & .077 & .051 & 13 \\
& Tea & .011 & .007 & 13 \\
& Total & .046 & .062 & 52 \\
& Saliva & -.010 & .048 & 13 \\
\cline { 2 - 3 } Polished & Orange juice & .129 & .132 & 13 \\
\cline { 2 - 5 } & Coca-Cola & .087 & .046 & 13 \\
\cline { 2 - 5 } Total & Tea & .019 & .023 & 13 \\
& Total & .056 & .091 & 52 \\
& Saliva & -.004 & .034 & 26 \\
& Orange juice & .110 & .110 & 26 \\
& Coca-Cola & .082 & .048 & 26 \\
& Tea & .015 & .017 & 26 \\
& Total & .051 & .078 & 104
\end{tabular}

\section{DISCUSSION}

Ceramics are known as inert dental materials, which can retain their integrity in different environments. However, previous studies have reported degradation of some types of porcelain ceramics in different solutions [2428,30 ]. Butler et al. [24] showed that $1.23 \%$ acidulated phosphate fluoride treatment increased the surface roughness of feldspathic porcelain, low-fusing porcelain and aluminous porcelain. Esquivel-Upshaw et al. [25] evaluated the ion exchange of glass ceramic veneers in acidic environments and concluded that ceramic veneers may be susceptible to considerable degradation in low- and high-pH buffering solutions. Junpoom et al. [26] evaluated the surface changes of fluorapatiteleucite and fluorapatite ceramics using various storage media and concluded that pineapple juice, green mango, cola and $4 \%$ acetic acid significantly increased the surface roughness of both ceramics.

Similarly, the results of the current study demonstrated that ZLS ceramics were not as impervious as they are thought to be. The results of measuring and comparing the surface roughness of specimens in this study revealed that the surface roughness of ZLS ceramics increased following immersion in different solutions, which rejected the null hypothesis of the study. Orange juice, cola and tea are some of the commonly consumed soft drinks worldwide that contain some acidic agents (which can cause dental erosion) and some other organic acids. Orange contains ascorbic acid, also known as vitamin C. Other acids that contribute to the nutritional profile oforange include folic, pantothenic, hydroxycinnamic, citric, malic and oxalic acids. The same acidity applies to juice from orange as well, which is also acidic. Black tea is mildly acidic, since its average $\mathrm{pH}$ level ranges from 4.9 to 5.5. More water may decrease its acidity [35]. Oxalate and citrate are the major anions in tea. It also contains anions such as fluoride, acetate, chloride, sulfate, nitrate and phosphate, which can cause dental erosion [36]. The three most common acids in cola include citric, carbonic and phosphoric acids. These acids can decalcify the tooth structure [37]. The chelating effect of these acids can cause degradation, ionic dissolution and release of alkaline lithium and aluminum ions and result in dissolution of the ceramic silicate network, which can be toxic [27,28,31,38].

According to the current findings, immersion of ceramics in orange juice, cola and tea created some degrees of surface roughness, albeit the surface roughness caused by immersion in tea was low and not significant. Saliva, as the control group, also caused roughness of ceramic, but not significantly. Precedent studies have demonstrated that increased surface roughness of dental porcelain due to degradation can decrease its strength $[23,28,39]$.

Table 3. Comparison between solutions using Tukey's HSD test

\begin{tabular}{lllllll} 
Solution & Solution & $\begin{array}{l}\text { Mean } \\
\text { Difference }\end{array}$ & $\begin{array}{l}\text { Standard } \\
\text { Error }\end{array}$ & P-value & \multicolumn{2}{c}{ 95\% Confidence Interval } \\
& Lower Bound & Upper Bound \\
Orange & Saliva & .114 & .017 & $<.001$ & .072 & .157 \\
Cola & Saliva & .086 & .017 & $<.001$ & .044 & .128 \\
Tea & Saliva & .019 & .017 & .562 & -.022 & .061 \\
\hline
\end{tabular}


Other studies have claimed that higher surface roughness can cause higher bacterial plaque accumulation and gingival inflammation [11,14-19]. Ceramic failure may occur as the result of increased surface roughness due to repeated exposure to the studied solutions.

Kamala and Annapurni [40] evaluated the surface roughness changes of glazed and polished ceramic following exposure to fluoride gel, bleaching agent and aerated drink and reported significantly higher mean $\mathrm{Ra}$ values for glazed surfaces before exposure to the acidic solutions. They also showed that glazed surfaces had higher mean $\mathrm{Ra}$ values after exposure, but not significantly [40]. In the present study, glazed specimens had lower surface roughness before and after immersion, compared with polished specimens, although this difference was not significant. The efficacy of polishing to achieve a smooth ceramic surface is still a controversial topic. Some authors believe that roughness of polished surfaces is equal to that of glazed surfaces, while some others disclaim this statement [14, 41-44].

\section{CONCLUSION}

Based on the findings of this study, the following conclusions were drawn:

Orange juice and cola significantly increased the surface roughness of both polished and glazed ZLS ceramics. The surface roughness of polished and glazed ceramics was not significantly different following immersion in different solutions.

\section{ACKNOWLEDGMENTS}

This study was supported by Hamadan University of Medical Sciences, Hamadan, Iran.

\section{CONFLICT OF INTEREST STATEMENT}

None declared.

\section{REFERENCES}

1. Giordano RA. Dental ceramic restorative systems. Compendium of continuing education in dentistry (Jamesburg, NJ: 1995).1996;17(8):779-82.

2. Wohlwend A, Strub JR, Schärer P. Metal ceramic and all-porcelain restorations: current considerations. Int J Prosthodont. 1989 Jan-Feb;2(1):13-26.

3. Motro PF, Kursoglu P, Kazazoglu E. Effects of different surface treatments on stainability of ceramics. J Prosthet Dent. 2012 Oct;108(4):231-7 .

4. Son HJ, Kim WC, Jun SH, Kim YS, Ju SW, Ahn JS. Influence of dentin porcelain thickness on layered all-ceramic restoration color. J Dent. 2010;38 Suppl 2:e71-7 .

5. Elsaka SE, Elnaghy AM. Mechanical properties of zirconia reinforced lithium silicate glass-ceramic.Dent Mater. 2016 Jul;32(7):908-14 .

6. Sen N, Us YO. Mechanical and optical properties of monolithic CAD-CAM restorative materials. J Prosthet Dent. 2018 Apr;119(4):593-599.

7. Suprinity V. Technical and scientific documentation. Vita Zahnfabrik, Bad Säckingen, Germany. 2014:5. Available at: https://panadent.co.uk/wpcontent/uploads/2014/10/Vita-SuprinityTechnical-and-Scientific-Document.pdf

8. Traini T, Sinjari B, Pascetta R, Serafini $\mathrm{N}$, Perfetti G, Trisi $\mathrm{P}$, et al. The zirconiareinforced lithium silicate ceramic: lights and shadows of a new material. Dent Mater J. 2016 Oct 1;35(5):748-755 .

9. Jacobi R, Shillingburg HT Jr, Duncanson MG Jr. A comparison of the abrasiveness of six ceramic surfaces and gold. J Prosthet Dent. 1991 Sep;66(3):303-9.

10. Jagger DC, Harrison A. An in vitro investigation into the wear effects of unglazed, glazed, and polished porcelain on human enamel. J Prosthet Dent. 1994 Sep;72(3):320-3. 11. Klausner LH, Cartwright CB, Charbeneau GT. Polished versus autoglazed porcelain surfaces. J Prosthet Dent. 1982 Feb;47(2):157-62.

12. Newitter DA, Schlissel ER, Wolff MS. An evaluation of adjustment and postadjustment finishing techniques on the surface of porcelain-bonded-to-metal crowns. J Prosthet Dent. 1982 Oct;48(4):388-95.

13. Patterson CJ, McLundie AC, Stirrups DR, Taylor WG. Efficacy of a porcelain refinishing system in restoring surface finish after grinding with fine and extra-fine 
diamond burs. J Prosthet Dent. 1992 Sep;68(3):402-6.

14. Carlén A, Nikdel $\mathrm{K}$, Wennerberg A, Holmberg K, Olsson J. Surface characteristics and in vitro biofilm formation on glass ionomer and composite resin. Biomaterials. 2001 Mar;22(5):481-7 .

15. Hulterström AK, Bergman M. Polishing systems for dental ceramics. Acta Odontol Scand. 1993 Aug;51(4):229-34.

16. Jung M, Wehlen O, Klimek J. Finishing and polishing of indirect composite and ceramic inlays in-vivo: occlusal surfaces. Oper Dent. 2004 Mar-Apr;29(2):131-41.

17. Kou W, Molin M, Sjögren G. Surface roughness of five different dental ceramic core materials after grinding and polishing. J Oral Rehabil. 2006 Feb;33(2):117-24.

18. Quirynen M, Bollen CM. The influence of surface roughness and surface-free energy on supra- and subgingival plaque formation in man. A review of the literature. J Clin Periodontol. 1995 Jan;22(1):1-14.

19. Wright MD, Masri $\mathrm{R}$, Driscoll $\mathrm{CF}$, Romberg E, Thompson GA, Runyan DA. Comparison of three systems for the polishing of an ultra-low fusing dental porcelain. J Prosthet Dent. 2004 Nov;92(5):486-90.

20. Lee YK, Lim BS, Kim CW. Effect of surface conditions on the color of dental resin composites. J Biomed Mater Res. 2002;63(5):657-63.

21. Obregon A, Goodkind RJ, Schwabacher WB. Effects of opaque and porcelain surface texture on the color of ceramometal restorations. J Prosthet Dent. 1981 Sep;46(3):330-40.

22. Tuncdemir AR, Dilber E, Kara HB, Ozturk AN. The effects of porcelain polishing techniques on the color and surface texture of different porcelain systems. Mater Sci Appl.2012 May;3(5):294-300.

23. de Jager N, Feilzer AJ, Davidson CL. The influence of surface roughness on porcelain strength. Dent Mater. 2000 Nov;16(6):381-8.

24. Butler CJ, Masri R, Driscoll CF, Thompson GA, Runyan DA, Anthony von Fraunhofer J. Effect of fluoride and 10\% carbamide peroxide on the surface roughness of low-fusing and ultra low-fusing porcelain. J Prosthet Dent. 2004 Aug;92(2):179-83.

25. Esquivel-Upshaw JF, Dieng FY, Clark AE, Neal D, Anusavice KJ. Surface degradation of dental ceramics as a function of environmental pH. J Dent Res. 2013 May;92(5):467-71.

26. Junpoom $P$, Kukiattrakoon B, Hengtrakool C. Surface characteristic changes of dental ceramics after cyclic immersion in acidic agents and titratable acidity. Eur J Prosthodont Restor Dent. 2010 Dec;18(4):177-84.

27. Kukiattrakoon B, Hengtrakool C, Kedjarune-Leggat $U$. The effect of acidic agents on surface ion leaching and surface characteristics of dental porcelains. J Prosthet Dent. 2010 Mar;103(3):148-62 .

28. Kukiattrakoon B, Hengtrakool C, Kedjarune-Leggat U. Effect of acidic agents on surface roughness of dental ceramics. Dent Res J (Isfahan). 2011 Winter;8(1):6-15.

29. Kukiattrakoon B, Junpoom $P$, Hengtrakool C. Vicker's microhardness and energy dispersive $\mathrm{x}$-ray analysis of fluorapatite-leucite and fluorapatite ceramics cyclically immersed in acidic agents. J Oral Sci. 2009 Sep;51(3):443-50.

30. Vechiato-Filho AJ, Dos Santos DM, Goiato MC, Moreno A, De Medeiros RA, Kina S, Rangel EC, et al. Surface degradation of lithium disilicate ceramic after immersion in acid and fluoride solutions. Am J Dent. 2015 Jun;28(3):174-80.

31. Anusavice KJ. Degradability of dental ceramics. Adv Dent Res. 1992 Sep;6:82-9.

32. Alp G, Subasi MG, Johnston WM, Yilmaz B. Effect of surface treatments and coffee thermocycling on the color and translucency of CAD-CAM monolithic glass-ceramic. J Prosthet Dent. 2018 Aug;120(2):263-268.

33. Wang $\mathrm{F}$, Takahashi $\mathrm{H}$, Iwasaki $\mathrm{N}$. Translucency of dental ceramics with different thicknesses. J Prosthet Dent. 2013 Jul;110(1):14-20 .

34. Turssi CP, Hara AT, de Magalhães CS, Serra MC, Rodrigues AL Jr. Influence of storage regime prior to abrasion on surface topography of restorative materials.J Biomed 
Mater Res B Appl Biomater. 2003 May 15;65(2):227-32.

35. Marcus JB. Culinary nutrition: the science and practice of healthy cooking. Academic Press, Marcus JB, 2013, IL, USA:77.

36. Simpson A, Shaw L, Smith AJ. Tooth surface $\mathrm{pH}$ during drinking of black tea. $\mathrm{Br}$ Dent J. 2001 Apr 14;190(7):374-6.

37. Borjian A, Ferrari CC, Anouf A, Touyz LZ. Pop-cola acids and tooth erosion: an in vitro, in vivo, electron-microscopic, and clinical report. Int J Dent. 2010;2010:957842.

38. Anusavice KJ, Zhang NZ. Chemical durability of Dicor and lithia-based glassceramics. Dent Mater. 1997 Jan;13(1):13-9.

39. Kelly JR, Giordano R, Pober R, Cima MJ. Fracture surface analysis of dental ceramics: clinically failed restorations. Int J Prosthodont. 1990 Sep-Oct;3(5):430-40.

40. Kamala K, Annapurni H. Evaluation of surface roughness of glazed and polished ceramic surface on exposure to fluoride gel, bleaching agent and aerated drink: An in vitro study. J Indian Prosthodont Soc. 2006;6(3):128.

41. Sulik WD, Plekavich EJ. Surface finishing of dental porcelain. Prosthet Dent. 1981 Aug;46(2):217-21.

42. Tholt de Vasconcellos B, MirandaJúnior WG, Prioli R, Thompson J, Oda M. Surface roughness in ceramics with different finishing techniques using atomic force microscope and profilometer. Oper Dent. 2006 Jul-Aug;31(4):442-9 .

43. Bessing C, Wiktorsson A. Comparison of two different methods of polishing porcelain. Scand J Dent Res. 1983 Dec;91(6):482-7.

44. Aykent F, Yondem I, Ozyesil AG, Gunal SK, Avunduk MC, Ozkan S. Effect of different finishing techniques for restorative materials on surface roughness and bacterial adhesion. J Prosthet Dent. 2010 Apr;103(4):221-7. 